\title{
Abnormal Pressure Distribution of Tertiary age formations in Middle \& South Iraqi Oil Fields
}

\author{
Dr. Faleh H. M. Almahdawi*; Dr. Kareem A. Alwan**; Ahmed K. H. Alhusseini** \\ *Petroleum Engineer Department, University of Baghdad;**PRDC
}

\section{Abstract}

Prediction of formation pore pressure gradient is a very important factor in designing drilling well program and it help to avoid many problems during drilling operations such as lost circulation, kick, blowout and other problems.

In this study, abnormal formation pressure is classified into two types; abnormal high pressure (HP) and abnormal low pressure (LP), therefore any pressure that is either above or below the hydrostatic pressure is referred to as an abnormal formation pressure.

This study concerns with abnormal formation pressure distribution and their effect on drilling operations in middle \& south Iraqi oil fields. Abnormal formation pressure maps are drawn depending upon drilling evidence and problems.

Three formations are considered as abnormal formations in the region of study, these formations geologically existed in Tertiary age and they from shallower to deeper are: Lower Fars, Dammam and Umm Er Radhuma, Formations. The maps of this study referred to either high formations pressure such as (Lower Fars and Umm Er Radhuma) or the low formations pressure such as (Dammam) in middle and south of Iraq. Finally these maps also suggested and showed the area, where no field is drill until now, which may behave as high, low and normal formation pressure for every formation understudy.

Keywords: Abnormal formation maps, distribution, abnormal low pressure, abnormal high pressure, Lower Fars, Dammam, Umm Er Rathuma. 


\section{1 -Introduction}

Abnormal formation pressures are encountered throughout the world and it produced by many different causes that may be physical, chemical, or a combination of the two. Many reasons for the formation of subsurface abnormal fluid pressures have been postulated and discovered. Abnormally high pressured formations, recorded at depths of a few hundred feet to that greater than 20,000 ft. These formations have fluids were isolated environments or the fluid movement to flow out of the formation is restricted. The total overburden load is partially supported by the pore fluids. These abnormally formations can only exist if the formation is separated by impermeable barriers that contain the pressure in the reservoir [1].

Formations which exhibit a pressure deviation towards higher or lower formation pressure rather than the normal hydrostatic pressure commonly, because drilling problems. Some of these problems are; lost circulation, lost hole, stuck drill pipe, flowing fluid (salt water or hydrocarbon) into well, blow out and casing setting problems ( at soft or fracture formations). Any one of these or together associated with abnormal pressure will increase drilling costs [2].

In Iraq, there is enough drilling experience to nominate the abnormal pressure formations. These formations make real challenges to well construction operations in most of Iraqi oil fields.

Pore pressures gradient can be divided into two forms normal pore pressure gradient and abnormal low and high pore pressure gradient. In fact, the formation pressures is low pressure (Subnormal) when its pressure is less than normal pressure gradient $0.465 \mathrm{psi} / \mathrm{ft}$, while the formation pressure is high pressure (Overpressured) when its pressure is greater than normal pressure gradient $0.465 \mathrm{psi} / \mathrm{ft}$. The reason which creates this abnormality in pore pressures may be very complex and vary from one region to another [3].

For that, it is very important to predict and detect abnormal pressure zones, where there are many risks such as loss of drilling fluids, kicks, blowout and other difficulties. In addition, it is also very important to predict the pressure at which the rocks will fracture. These fractures can result in losses of large volumes of drilling fluids. [3] 
Notable effects of high formation pressure that are costly include the following [4]:

- Blowouts - uncontrolled production of formation fluids

- Caving-high pore pressure in low permeability rocks causes them to stress relieve or "cave" into the borehole

- Stuck pipe-the drill pipe adheres to the side of the borehole due to the swelling (stress relief) of the borehole walls behind the bit

- Lost circulation - the lost circulation may occur when raising the mud weight in order to control the formation pressure at the bit, the formation may rupture while hydrostatic pressure exceed formation pressure. The mud will then run out into a cavity of its own making.

When drilling in areas where high pressure zones are exist, it is necessary to be aware of both the pressure of the fluids in the pores and the pressure at which the formations willfracture. [4].

Subnormal (abnormal low) formations pressures, (less than 0.465 psi per $\mathrm{ft}$ of depth), are very common. The cause of abnormal formation low pressures is not well understood. If a formation containing either gas or oil is isolated and then subjected to uplift and erosion. Subnormal formation pressured has much less attention than to high formation pressure. This is probably because there are fewer spectacular drilling problems associated with subnormal pressures and underpressures. However, problems exist that can be serious [5]. 


\section{Causes of Overpressured Formation $[2,6]$}

(a) Incomplete sediment compaction or undercompaction:

(b) Faulting

(c) Massive Rock Salt Deposition

(d) Phase Changes while Compaction

(e) Repressuring from Deeper Levels

(f) Generation of Hydrocarbons

(g) Osmosis as a factor for generation of abnormal pressure

\section{Drilling problems with Low (subnormally) pressured reservoirs [4,5]}

Much less attention has been paid to subnormally pressured reservoirs than to overpressured reservoirs. This is probably because there are fewer spectacular drilling problems associated with subnormal pressures and underpressures. However, problems exist that can be serious.

If the reservoir pressure is much lower than the pressure of the drilling fluid, severe formation damage can occur. The drilling mud filtrate penetrates the reservoir, causing swelling and migration of clays, which may plug the pore throats. Even a little water in the hole can kill a low pressure producing gas well. The water is drawn into the pores by capillarity and ruins the relative permeability to gas. In the case of low pressure gas sandstone reservoirs, it is desirable to set casing at the top of the reservoir interval and drill with gas, salt water, or oil-based mud to minimize formation damage.

Also, if the gas reservoir has a low pressure, there may be no indication of gas on the mudlog. The logs of many abandoned dry holes should be reexamined to look for bypassed gas zones. 


\section{Causes of Low (Subnormal) Formation Pressure[2,6]:}
a) Formation Foreshortening
b) Thermal Expansion
c) Depletion
d) Potentiometric Surface:

\section{Area of Study}

The basic map for this study was designed at geology section in Exploration Oil Company in the Ministry of Oil. Finally, the locations for 35 fields (one well for each field) are established into basic map as shown in figure (1) and listed in table (1). 


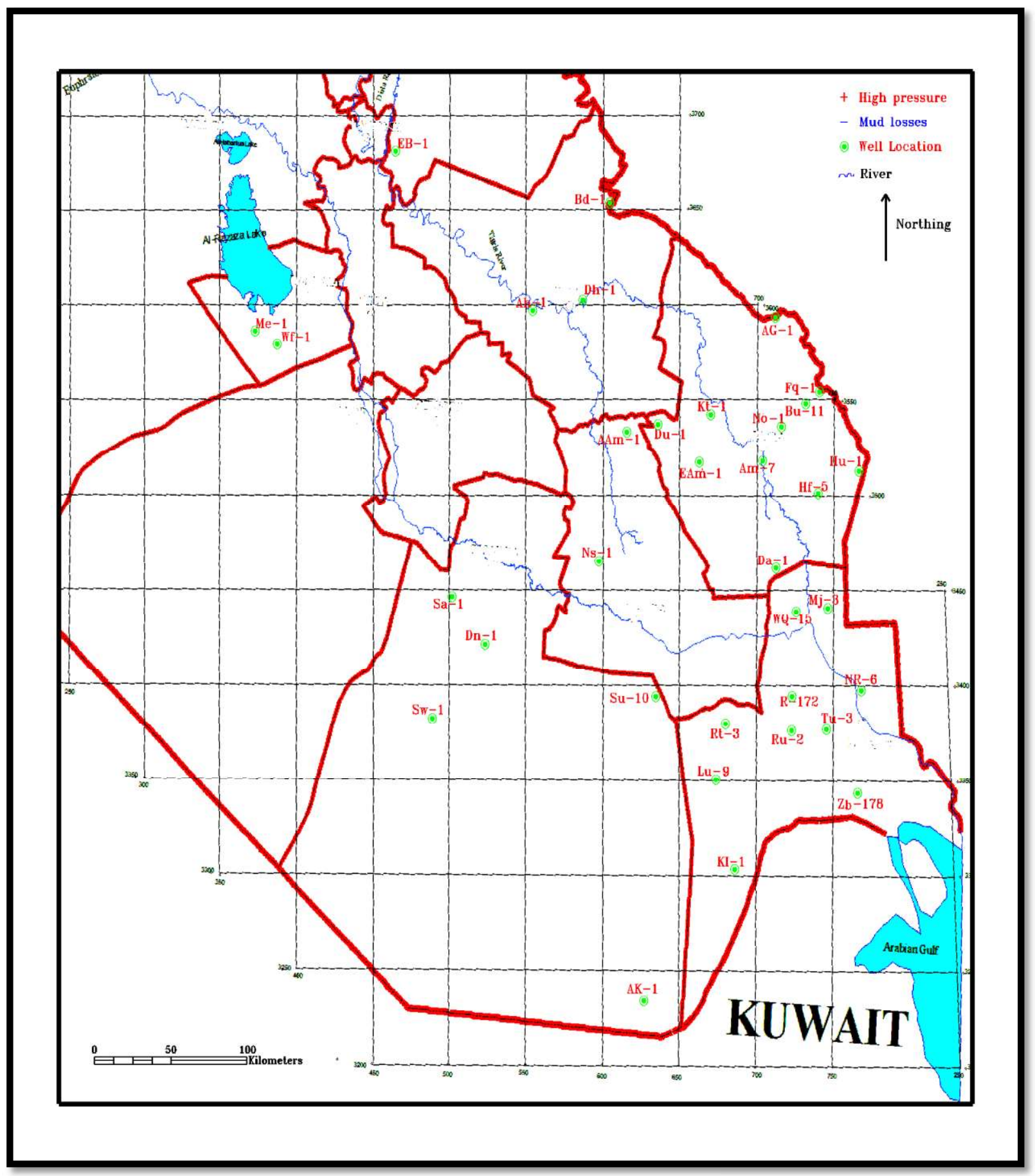

Fig. (1) Map shows all wells under study

The data used in this study to draw and establish Formation pressure distribution maps were obtained from final well reports, final drilling reports and final geological reports. Abnormal low pressure and abnormal high pressure formations were indicated from mud losses 
and flowing (water and gas) events. Mud density of wells under study and Stratigraphy columns of 35 fields in middle-southern region of Iraq were studied as well.

This study includes both shallow and deep wells, and includes many exploration and production wells in order to take the larger area with different locations that permit to compare and connect between the same formations which have the same behavior of abnormality pressure (high or low). Table (1) gives the range of depth which is considered in the present study for each well.

Table (1) fields under study [7-9]

\begin{tabular}{|lllll|}
\hline No & Fields/Well & Surface formation & TD & Tops (M) \\
\hline 1 & Abu Amood (AAm-1) & Upper Fars & Najmah & $(0-4636)$ \\
\hline 2 & Abu Amood (EAA-1) & Upper Fars & Sulaiy & $(0-4415)$ \\
\hline 3 & Amara (Am-7) & Bakhtiary \& Upper Fars & Rumaila & $(0-3077.5)$ \\
\hline 4 & Diwan (Dn-1) & Rus/Umm-er-Radhuma & Chiazairi & $(0-5210)$ \\
\hline 5 & Samawa (Sa-1) & Dammam & Batmah & $(105-3730)$ \\
\hline 6 & Kumati (Kt-1) & Upper Fars & Sulaiy & $(0-4405)$ \\
\hline 7 & Huwaiza (Hu-1) & Upper Fars & Zubair & $(0-4090)$ \\
\hline 8 & Dhifirya (Dh-1) & Bakhtiary \& Upper Fars & Ratawi & $(0-4398)$ \\
\hline 9 & Nasiriya (Ns-1) & Alluvium & Gotnia & $(0-3624)$ \\
\hline 10 & Noor (No-1) & Upper Fars & Sulaiy & $(0-4742)$ \\
\hline 11 & Nahr Umr (NR-6) & Alluvium & Shuaiba & $(0-2604)$ \\
\hline 12 & Badra (Bd-1) & Bakhtiary \& Upper Fars & Nahr Umr & $(0-5002)$ \\
\hline 13 & East Baghdad (EB-1) & Alluvium & Adatiya & $(4.5-4839.5)$ \\
\hline 14 & Khider Al Mae (KI-1) & Dibdibba & Butmah & $(0-5561)$ \\
\hline 15 & Ahdab (Ah-1) & Bakhtiary \& Upper Fars & Ratawi & $(0-3996)$ \\
\hline 16 & Majnoon (Mj-3) & Alluvium & Sulaiy & $(0-4215)$ \\
\hline 17 & Halfaya (Hf-5) & Alluvium & Sulaiy & $(0-4444.5)$ \\
\hline 18 & North Rumaila (R-172) & Dibdibba & Butmah & $(0-5131)$ \\
\hline & & & & \\
\hline
\end{tabular}




\begin{tabular}{|lllll|}
\hline 19 & Zubair (Zb-178) & Dibdibba & Zubair & $(0-3089)$ \\
\hline 20 & Shawiya (Sw-1) & Dammam & Zubair & $(60-1784)$ \\
\hline 21 & Subba (Su-10) & Dibdibba & Zubair & $(0-2715)$ \\
\hline 22 & West Kifl (WK-1) & Upper Fars & Chaizeri & $(0-5323)$ \\
\hline 23 & Merjan (Me-1) & Dibdibba & Sargelu & $(0-2712)$ \\
\hline 24 & Abu Khema (AK-1) & Dibdibba & Butmah & $(0-4430)$ \\
\hline 25 & Buzurkan (Bu-11) & Alluvium & Rumaila & $(0-4063)$ \\
\hline 26 & Dimah (Da-1) & Upper Fars & Yamama & $(0-3939)$ \\
\hline 27 & Faqa (Fq-1) & Bakhtiary \& Upper Fars & Nahr Umr & $(0-4683)$ \\
\hline 28 & Luhais (Lu-9) & Dibdibba & Zubair & $(0-2732)$ \\
\hline & South Rumaila & & & \\
29 & (Ru-2 \& Ru-72) & Dibdibba & Zubair & $(0-3196)$ \\
\hline 30 & Tuba (Tu-3) & Dibdibba & Rumaila & $(0-2455)$ \\
\hline 31 & Ratawi (Rt-3) & Dibdibba & Gotnia & $(0-4077)$ \\
\hline 32 & West Qurna (WQ) & Upper Fars & Najmah & $(0-4400)$ \\
\hline 33 & Sindibad (SND-2) & Hammar & Sulaiy & $(0-4326)$ \\
\hline 34 & Abu Garab (AG-3) & Upper Fars & Shuaiba & - \\
\hline 35 & Dujaila & & & $(0-4125)$ \\
\hline
\end{tabular}

\section{1- Results and discussion}

In this research, the work focused on finding a way to draw the distribution of abnormal pressure zones on the basis of each formation separately maps. Therefore, depending upon final drilling and geological well reports, the formations in which problems have been occurred where identified. These problems go back to many reasons such as Compaction, Aquathermal effect, Artisan condition, Osmosis, Hydrocarbon production, Paleopressure, Evaporation rocks, Rapid sedimentation, Uplift, Rehydration of anhydrite, tectonic activity and impact of fluid within these formations $[1,2]$. These reasons may lead to make the formation to be in abnormal pressure behavior. 
The maps are divided in two kinds, first; on the basis of high pressures (upper than normal trend, may be called Overpressure or Geopressure). This case causes the entry and flow of fluids into the well, which may cause a change in the density of the drilling fluid, which may lead to a kicked well problem or blow out. In some cases when fluid which entered the well is in high density which will increase hydrostatic pressure against the drilled formation then causing drilling fluid loss problems. Second; on the basis of Low pressures (less than normal trend, may be called Subpressure). This case causes of the entry and flow of the drilling mud into the formation, then lost circulation problems. In some cases it results in a reverse process like a kickoff problem. In this case the drilling fluid which losses into formation leads to reduce the hydrostatic column of drilling mud then reduce the hydrostatic pressure against formation, thus formation pressure overcomes on hydrostatic pressure and formation fluid enters the well.

\section{ENVI ( "Environment for Visualizing Images")}

It is a software application used to process and analyze geospatial imagery. It is commonly used by remote sensing professionals and image analysts. ENVI combines advanced image processing and proven geospatial analysis technology to help in extract meaningful information and make better decisions [10].

This program has been used to draw a map that shows the basic study area (southern and central Iraq), and also to install locations of wells according to UTM coordinate (Northing \& Easting) system which have been identified from final drilling and geological well reports.

The maps are divided in two kinds, first; on the basis of high pressures (upper than normal trend, may be called Overpressure or Geopressure). This case causes the entry and flow of fluids into the well, which may cause a change in the density of the drilling fluid, which may lead to a kicked well problem or blow out. In some cases when fluid which entered the well is in high density which will increase hydrostatic pressure against the drilled formation then causing drilling fluid loss problems. Second; on the basis of Low pressures (less than normal trend, may be called Subpressure). This case causes of the entry and flow of the drilling mud into the formation, then lost circulation problems. In some cases it results in a reverse process like a 
kickoff problem. In this case the drilling fluid which losses into formation leads to reduce the hydrostatic column of drilling mud then reduce the hydrostatic pressure against formation, thus formation pressure overcomes on hydrostatic pressure and formation fluid enters the well.

In fact, oilfield drilling operations in central and southern Iraq accompanied by several problems so that these problems vary from one to another field depending on the sequence of the formations and their pore pressure.

Many exploratory wells were selected in this study because they can: 1-Give aclear idea of real problems that have been occurred when drilling these wells.

2-These wells drilled as deeper wells, approximately, the depth of these wells range between (1800-5400) meters.

Other production and appraisal wells were selected with consideration of their depth and the importance of the field in middle and south of Iraq.

The review of these formations is the aim of the current study; finally, these formations are drawn and illustrated the distribution of abnormal pressure in maps which designed for the first time.

\section{2- Formations Under Study}

Three formations selected in this research for studying and for drawing pressure distribution maps, which existed specially in geological sequence of Tertiary age, depending upon drilling evidence and problems. These formations from shallower to deeper are: Lower Fars, Dammam and Umm Er Radhuma as follows:

\section{4-1- Lower Fars Formation}

This formation is considered as one of the most important formations within the geological sequence inside Iraq. It is apparent in most of central and southern Iraq of the Miocene Middle age. It's generally consists of shale layers, anhydrite and salt in addition to the presence of some sections of the dolomite [11]. 
This formation is appearing in most wells under study except the western part of Iraq. It had shown the abnormality only in the eastern part of Iraq near borders with Iran and especially in Missan oil fields. Finally; these wells are (AG-1, Fq-1, Hu-1, Hf-5, Kt-1, Du-1, EAA-1, Dh-1, Bd-1 and EB). Lower Fars is disappearing at western wells such as (Sa-1, Dn-1 and Sw-1). The Lower Fars formation is shown the abnormality high pressure behavior because this formation has salt and shale sections in its composition.

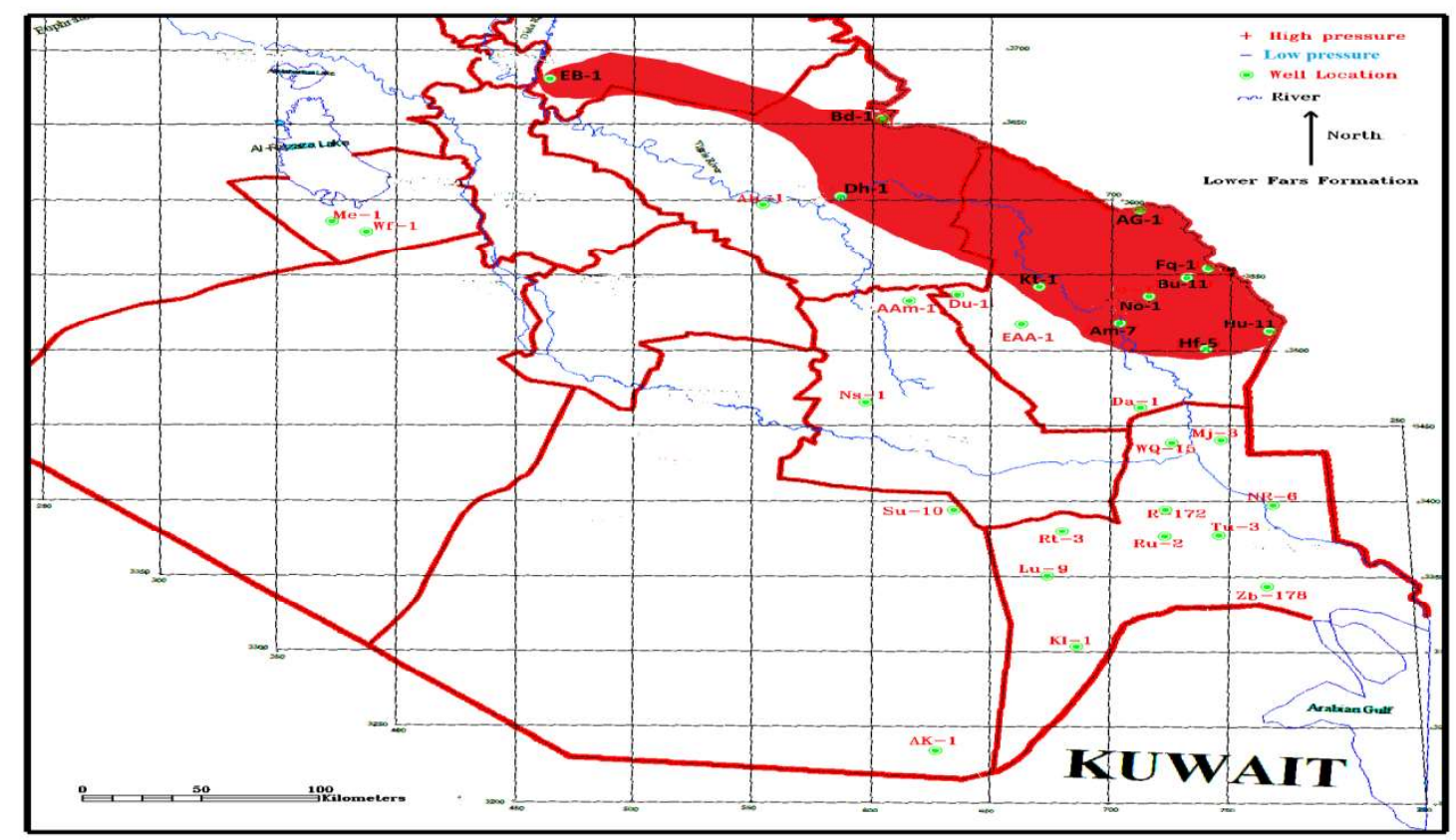

Fig.(2) Map shows the Abnormal High Pressure in Lower Fars Formation distribution at south and middle Iraqi oil fields.

From figure (2) noted that driller should be careful while drilling Lower Fars Formation because the probability of salt water flowing is very high expected. Therefore; this map gives the briefly idea about this formation and expected the region that may this formation be found and acting as abnormal high pressure formation.

The pressure gradient in mentioned fields starts increasing after drilling about 70 meters into member (Mb5) of lower Fars Formation. Saturated salt mud is used to drill this formation 
with density starting from $2.15 \mathrm{gm} / \mathrm{cc}$ gradually increases to reach the upper density $2.30 \mathrm{gm} / \mathrm{cc}$. Mud density which used in Lower Fars formation at some wells is shown in figure (2).

In the wide area the deposition of salt can be occurred. In fact, the salt sections usually considered as impermeable sections for fluid movement, therefore the underlying formations are become in high pressure. The zones which are found directly below a salt layer, usually it will be in high pressure [6].

Table (2) density used to drill Lower Faris formation at different fields [7, 8, 9, 11].

\begin{tabular}{|c|c|c|c|}
\hline No.1 & Fields/wells & $\begin{array}{l}\text { Density used to drill } \\
\text { formation }(\mathrm{gm} / \mathrm{cc})\end{array}$ & $\begin{array}{l}\text { Remarks from final drilling, } \\
\text { geological and well reports }\end{array}$ \\
\hline 1 & Dhifirya (Dh-1) & $(1.42-1.46)$ & $\begin{array}{l}\text { A salt section causes difficulties } \\
\text { for conductivity the mud } \\
\text { parameters. (Used salt saturated } \\
\text { mud). }\end{array}$ \\
\hline 2 & Halfaya (Hf-5) & 2.25 & $\begin{array}{l}\text { Salt beds with Flowing salt } \\
\text { water. }\end{array}$ \\
\hline 3 & Huwaiza (Hu-1) & 2.18 & $\begin{array}{l}\text { Salt sections with Flowing salt } \\
\text { water. }\end{array}$ \\
\hline 4 & Faqa (Fq-1) & 2.2 & $\begin{array}{l}\text { Abnormal high pressure } \\
\text { comparison with upper and } \\
\text { lower layers. }\end{array}$ \\
\hline 5 & Abu Garab (AG-3) & 2.28 & $\begin{array}{l}\text { Abnormal high pressure } \\
\text { comparison with upper and } \\
\text { lower layers. }\end{array}$ \\
\hline 6 & Buzurkan (Bu-11) & 2.28 & $\begin{array}{lll}\text { Abnormal high } & \text { pressure } \\
\text { comparison with upper and } \\
\text { lower layers. }\end{array}$ \\
\hline 7 & Badra (Bd-1) & 2.22 & Salt sections. \\
\hline 8 & East Baghdad (EB-1) & 1.78 & $\begin{array}{l}\text { Salt section but drilled without } \\
\text { problems }\end{array}$ \\
\hline
\end{tabular}




\begin{tabular}{|l|l|l|l|}
\hline 9 & Kumati (Kt-1) & 2.15 & Shown abnormality pressure \\
\hline 10 & Amara (Am-7) & $(2.00-2.26)$ & $\begin{array}{l}\text { Abnormal high pressure } \\
\text { (Flowing salt water) }\end{array}$ \\
\hline 11 & Noor (No-1) & $(1.78-2.25)$ & $\begin{array}{l}\text { Abnormal high pressure } \\
\text { (Flowing salt water) }\end{array}$ \\
\hline
\end{tabular}

\section{4-2- Dammam Formation}

This formation is existed within the geological sequence of the Tertiary/Eocene age inside Iraq. It is apparent in south of Iraq, in Basrah province wells (KI-1, Lu-9, RT-3, Ru-2, R172, Tu-3, Zb-178, NR-6, WQ-15 and Mj-3), Al-Muthana province wells (Sw-1, Dn-1, Sa-1, Ak-1 and Su-10), Thi Qar province wells (Ns-1 and AAm-1), Missan province Fields only in (Du-1, EAA-1 and Da-1) as well as in middle just at (Me-1, WK-1 and Ah-1).

Problems: partial losses (less than $10 \mathrm{~m}$ 3per hour), sever losses (more than $10 \mathrm{~m}$ 3per hour), or total (complete losses) is occurring usually in the last third of Dammam. Therefore the Treatments of this situation should be by drilling at the lowest possible indicators of weighting on bit, flow rate and hydrostatic pressure to avoid causing the losses $[7,8,12]$. 


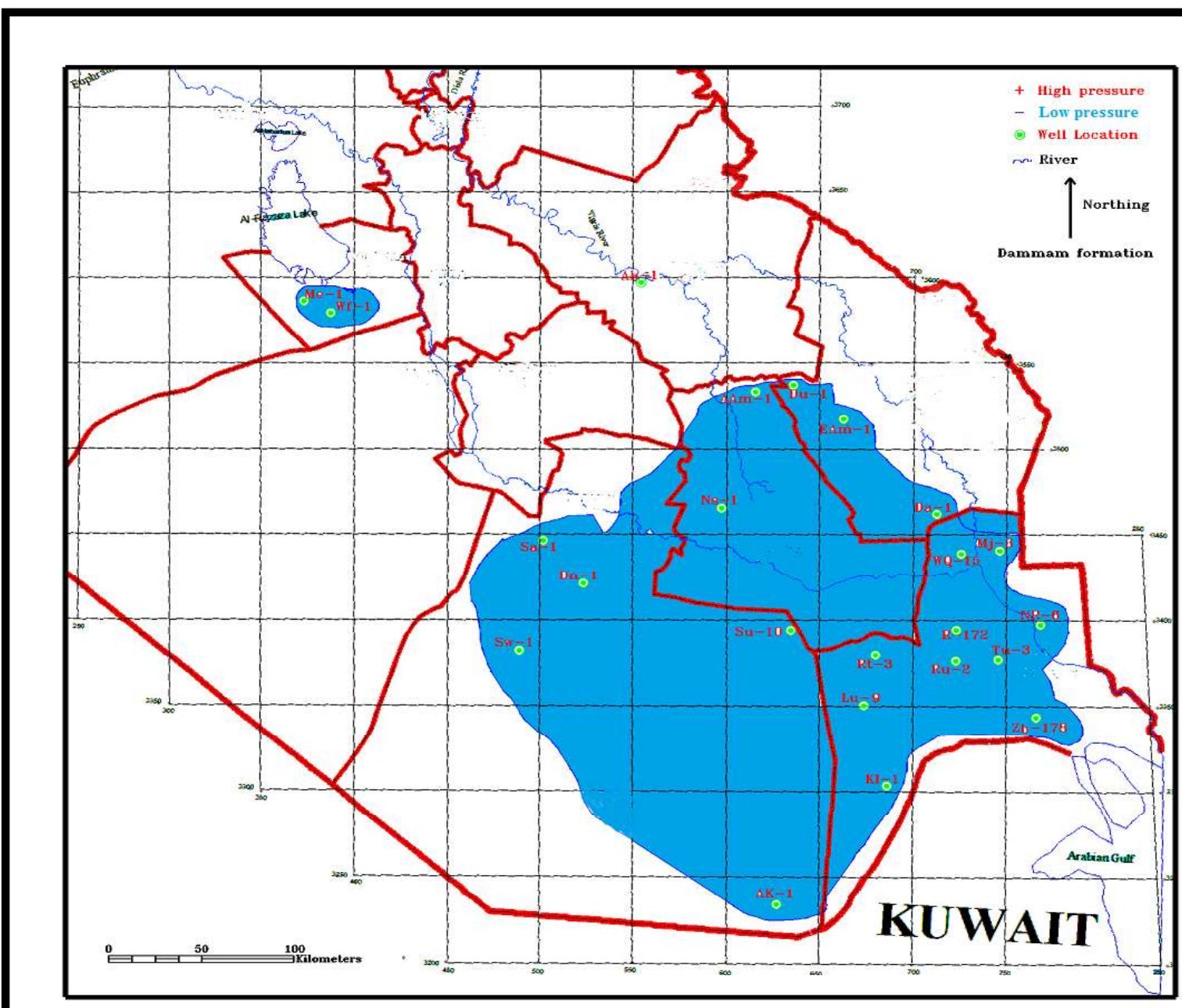

Fig. (3) Map shows the Abnormal Low Pressure (Mud Loss) in Dammam Formation distribution at south and middle Iraqi oil fields.

From figure (3) noted that driller should be careful while drilling Dammam Formation because the probability of occurring the mud loss is very high. Therefore this map gives the briefly indication about this formation and the ability to expected area which this formation may be existed and acting as abnormal low pressure formation.

In some bending of strata is founded during a compression process. The lower beds can bend downwards while the upper beds can bend upwards. The beds which existed in middle of them must expand to fill the space and therefore it create a low (subnormal) pressured zone, 
where it noted the high pressure can occurred in the top and bottom beds as a result of this phenomena.

A low pressured zone may result when hydrocarbons or water are produced from a formation in which no aquifer is founded. This case is take place especially during drilling a development wells through a reservoir which has already been producing for some time [6].

\section{4-3 Umm Er Rudhuma Formation}

This formation is existed within the geological sequence of the Tertiary/Paleocene age inside Iraq [13]. It is exist in south of Iraq, in Basrah province wells (KI-1, Lu-9, RT-3, Ru-2, R172, Tu-3, Zb-178, NR-6, WQ-15 and Mj-3), Al-Muthana province wells (Sw-1, Dn-1, Sa-1, Ak-1 and Su-10), Thi Qar province wells (Ns-1 and AAm-1), Missan province wells only in (Du-1, EAA-1 and Da-1) as well as in middle just at (Me-1, WK-1 and Ah-1).

Umm Er Radhuma formation is acting as high pressure and the probability of sulfur water flowing is very high, these wells defined with dark red color while the wells that expect to behave as abnormality high pressure defined with light red color such as (Sa-1, Rt-3, R-172 and Mj-3).Umm Er Radhuma formation is shown the abnormality high pressure behavior only at (KI-1, Lu-9, WQ-15, Ru-2, Tu-3, NR-6, Dn-1, Sw-1, AK-1 and Su-10) because this formation contain sulfurs water at these fields. As shown in Figure (4). 


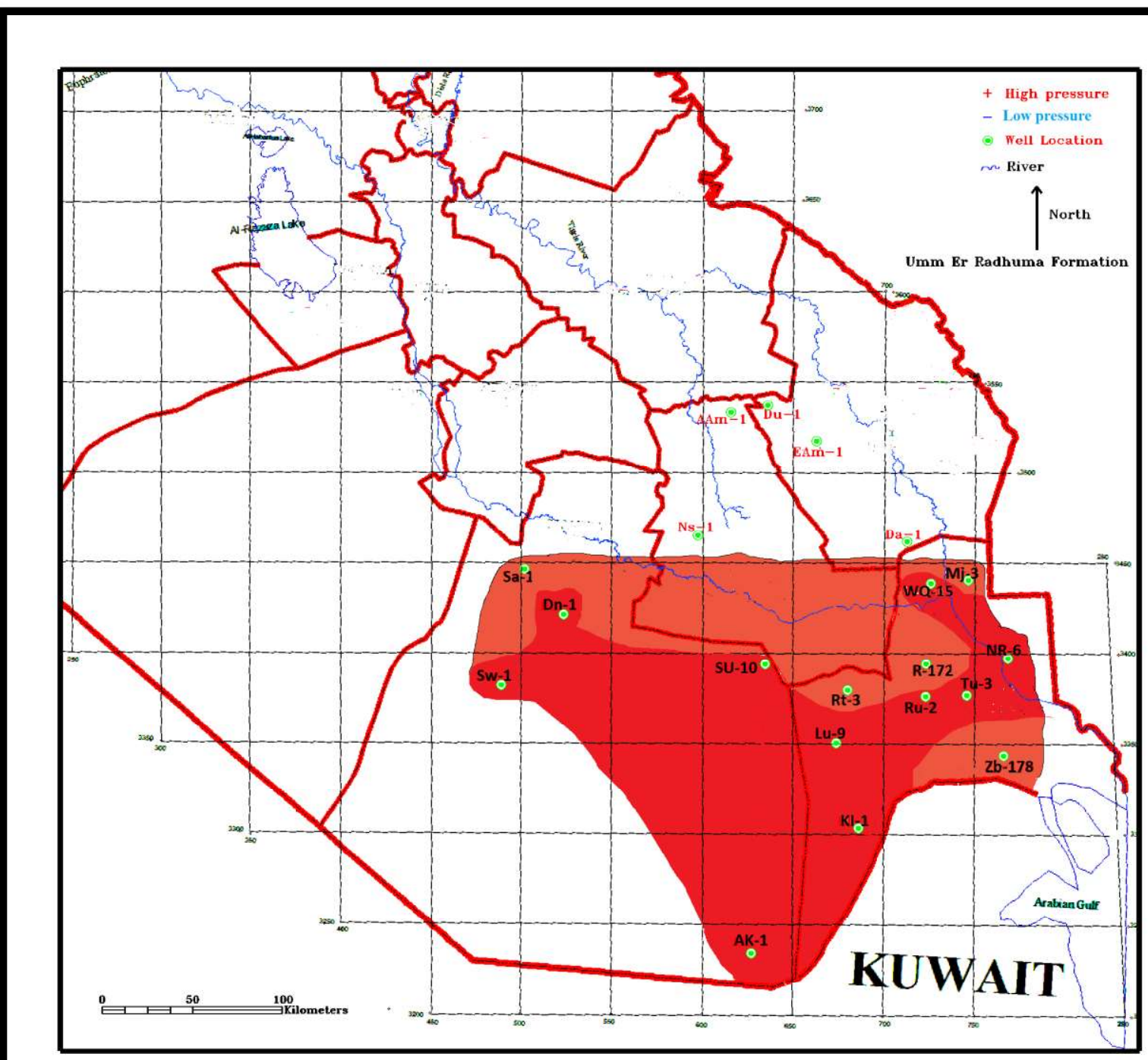

Fig. (4) Map shows the Abnormal High Pressure (Flowing sulfur water) in Umm Er Radhuma Formation distribution at south and middle Iraqi oil fields.

The migration of fluids from high pressure zones to low pressure zones at shallower depth may lead to this phenomenon. This may be caused by a poor job of casing cementing or by faulting. When the overpressure formations aren't estimated, the many problems will occurred such as flowing fluids, kick and blow out especially at no lithology change. If the sands are charge by gas from lower formations, they will lead to high pressures zones [6]. 


\section{Conclusions}

These maps created to determine the expect area of high pressure and low pressure of Tertiary geological sequence formations. The following conclusion is obtained by this study: 1.The Lower Fars formation is shown the abnormality high pressure especially in Missan province fields because this formation have salt and shale sections in its composition. The highest formation value of formation pressure is $2.28 \mathrm{gm} / \mathrm{cc}$ and it's located at Bu and AG.

2.Dammam formation showed abnormal low pressure at all fields understudy.

3.In some fields, Umm Er Radhuma formations showed the problems of losses while they mainly have abnormal high pressure (usually contain sulfur water), this problems occurred when used high mud weight to overcomes these abnormality.

\section{Recommendations}

1. When additional data to be provided such as resistivity, conductivity data and daily drilling reports, other methods can be used to predict both pore and fracture pressure gradient.

2. It is recommended to insert other wells in western of Iraq to create a clearest idea about pressure behavior in this region.

3. It is recommended to choose deep wells with complete data for all depth to estimate pressure for deeper formations.

4. Study the behaver of pressure (Low, High or Normal) formations in Cretaceous and Jurassic geological sequence. 


\section{References}

1. Rafiad K. A., "Prediction of Abnormal Formation Pressure in Southern Iraq", A Thesis Submitted to the College of engineering of the University of Baghdad, (1996).

2. G.V. Chilingar, V. A. Serebryakov and J. O. Robertson, "Origin and Prediction of Abnormal Formation Pressure", El sevier Science B.V. Amsterdam-Boston, (2002).

3. Institute of petroleum Eng., "Formation Pressure 5", Heriot Watt University.

4. Diana Morton-Thompson and Arnold M. Woods, "Development Geology Reference Manual", June (2013).

5. Dickey, P. A., Cox, W. C., "Oil and gas reservoirs with subnormal pressures": AAPG Bulletin, v. 61, n. 12, p. 2134-2142, (1977).

6. Tan Nguyen, "Well Design/chapter one Formation Pressure”, New Mexico Tech, (2013).

7. Ministry of oil, Oil Exploration Company, "Final drilling, geological and well reports" (1970-1980).

8. South oil company, "Final drilling, geological and well reports" (1974-2013).

9. Missan oil company, "Final drilling, geological and well reports" (1976-1984).

10.EARSC, "New ENVI software release from ITT introduces automated tools for image processing"(27-10-2009).

11. اكرم فاضل محمد وسعاد محمد نوري، "دراسة الضغط العالي (الغير الاعتيادي) في تكوين الفارس الاسفل لمعالجة

مشاكل الحفر في حقول ميسان"، بحث رقم 34/4/3، المؤسسة العامة لنفط الجنوب، دائرة نفط ميسان، بغداد، ايار

12. Information taking from the Experts Employees who working in the ministry of oil / oil Exploration Company and the Iraqi oil companies (SOC, MOC).

13.Saad Z. Jassim and Jeremy C. Goff, "Geology of Iraq”, (2006). 